\title{
Kazakhstan's Food Market: Conditions, Problems and Suggested Solutions
}

Mazken Zhanataevna Kamenova

Kazakh University of Economics, Finance and International Trade, Astana, Kazakhstan

Baglan Tulegenovna Aimurzina

Kazakh University of Economics, Finance and International Trade, Astana, Kazakhstan

Dametken Medihanovna Turekulova

Kazakh University of Economics, Finance and International Trade, Astana, Kazakhstan

Gulmira Nikolaevna Nakipova

Karaganda Economic University of the Kazakh Consumers' Union, Karaganda, Kazakhstan

Asel Abilkasimovna Akhmetova

Karaganda Economic University of the Kazakh Consumers' Union, Karaganda, Kazakhstan

Kulyanda Ainekovna Ahmetova

Karaganda Economic University of the Kazakh Consumers' Union, Karaganda, Kazakhstan

\section{Ainura Toyakovna Omarova}

Karaganda Economic University of the Kazakh Consumers' Union, Prikanalnaya 19 Street, Apt.375, Karaganda, Kazakhstan, 100000

\section{Doi:10.5901/mjss.2015.v6n3s3p185}

Abstract

The paper presents the results of the authors' theoretical and empirical research regarding the status of industries that form the food market, firstly agriculture as the main source of food products and raw materials for processing enterprises. Close attention is given to the analysis of the current situation of the foodstuff market, the need for AIC modernization is justified. The factors which impact the development of industry are considered, the analysis of the ratio of export, import and Kazakhstan's scope of essential food products was carried out. A market is a complex phenomenon with a hierarchical structure which changes in compliance with the current economic laws and situation. By its economic nature, a market is a self-regulating system of socio-economical processes whereby goods and services are produced, exchanged and sold. The economic importance of the food market is enhanced by its social significance which defines the priority of its support and management both at macro and micro-scale levels.

Keywords: food market, agricultural sector, food-processing industry, food supply, food security, export, import.

\section{Introduction}

An intrinsic structural element of the national market, the main function of which is to meet the population needs for food and industrial needs for raw material, is the food market. The performance of the food market includes all the stages of the production process, by its means there is an interaction between production and consumption and a balance between demand and supply (Tasmagambetova A.Zh., 2008).

The balance of the food market is reflected in: the ratio of the stock of food resources to its consumption; demand to supply; the cost of consumed food products compared to the standard of living, labour productivity to labour cost; 
market openness to protectionism; and it is the result of internal competition set by means of innovations, price reduction, improvement of product quality.

Demand for food products is determined by the physiological needs of the population and the production of the labour force. It can change, either grow or reduce, due to various factors. Its reduction is possible only to certain limits determined by simple production of individuals which defines its minimal boundary. The main factor facilitating the demand and limiting the possibilities of needs satisfaction is the real income of the population. Supply is formed by means of domestic production and food import and is implemented throughout trade enterprises. The food market impacts the field of foodstuff production, this influence is of a great significance, as it forms the scope and range of produced products, and defines the required amount of resources in production and processing industries.

The food market is marked by the highest degree of locality and autonomy, sustainable consumption of its products, low price elasticity and, most importantly, its strategic significance at all levels of management. The economic importance of the food market is enhanced by its social significance which defines the priority of its support and management both at macro and micro-scale levels. The boundaries of such support often exceed the limits of genuine market relations.

The formation and the effective performance of the food market is implemented by the interaction of various sectors of the economy, the integrity of which compiles the agro-industrial complex, the latter is traditionally comprised of three fields i.e. the production of producer goods for agriculture, the agriculture, food processing, its transportation and sales. The food market is linked to meeting the population needs; its stability and saturation depend on direct interaction with the labour market, as the purchasing power of the population is defined by their occupational level, rate of salaries and wages, pensions and benefits.

The most essential mechanism of the food market's formation is interaction between the production of agricultural products and the food-processing industry. While the market is being formed, a certain food chain is established: harvesting, sorting, processing of raw material, transporting, storing and selling the finished products which is the final stage of this chain.

On account of the social significance of the food market, it is highly important to carry out the monitoring of market conditions on a regular basis with the help of the indicators system. They can indicate favourable or unfavourbale tendencies, degrees of goods' competitiveness, decrease or increase of market share or scope of home-produced foodstuff, the adaptation level of market entities to new economic conditions and the adequacy of established relationships to the principles of the social market economy. The condition of the food market of any country can be assessed by analyzing: the capacity of the market; the level and history of the basic foodstuff consumption per groups of people with various capacities to pay debts; the level of a country's self-sufficiency for staple food products.

There are several possible scenarios to develop the national food market. Among them is the orientation to selfsufficiency, to focus on import with the purpose to create supply, an export-oriented scenario and etc. In our opinion, the second negative scenario is typical for the Kazakhstani market today, it is characterized by the market being filled mainly by imported products. To justify the concept of the food market's development, it is important to study the methods and instruments of government intervention which enable to form and maintain the food market in such a state which is adequate to new social conditions (Bayadinova A., 2006).

The President's Address to people of Kazakhstan, "Common goal, common interests, common future," states that "Kazakhstan has to become one of the major regional exporters of meat, dairy and other agricultural products. In horticulture it is necessary to reduce the volume of insufficiently profitable water-retaining crops and to replace them with vegetable, oil-bearing and feed products" (Nazarbayev N.A., 2014).

It should improve the status of Kazakhstan at the world food market and decrease the volume of imports.

\section{Method}

In Kazakhstan, at all stages of economic reforms, the problem of the country's food supply security stands out as one of the most important tasks in the development of the country. The strategic documents, which justify the reforms that are being held, state that the country's food security must be ensured, for this reason it is important to create incentives in order to attract investments in the agriculture and food industry, special attention should be paid to the growth of the most essential foodstuff production needs which are not being satisfied. The implementation of these tasks is closely linked to macroeconomic sustainability, the development of investment and innovative capacity, the demographic processes and labour market conditions. The increase of agricultural production and the development of the food industry become particularly relevant with regards to the objectives set in the Address. An economic boost in these sectors is particularly important for the stabilization of the domestic food market and food security provision, as they are essential conditions for 
sustainable development of Kazakhstan's economy.

To provide food security and to counter a possible threat of a food crisis, it is necessary to efficiently use the existing resources of all AIC fields. Meanwhile, the current state of Kazakhstan's food market is characterized by high external dependence. According to the Ministry of Agriculture (MA) Kazakhstan is only $60 \%$ self-sufficient in agricultural products, the other $40 \%$ is import that indicates the significant reliance of the domestic food market on imports and, as a result, growing market competition. In the most domestically consumed food products the proportion of import is as follows:

- Milk and condensed cream- $74,2 \%$,

- Confectionary products - 67,4,

- Cheese and curd cheese - 58,3,

- Sausage products $-44,8$,

- Butter -32,8\% and etc (Pereverzev I., 2014).

This situation is linked to a number of factors:

- The reduction in the production of a whole range of foodstuff and their replacement with imported products at the market;

- The destruction of the resource potential of agriculture and food industry;

- Inefficient food patterns - a low proportion of protein-based food to increasing proportion of consumed carbohydrates;

- Some vital food products are not economically available to certain group of people.

Kazakhstan's food market, in terms of globalization, becomes an integral part of the world food system. As a result, food supply difficulties that arise in the number of countries, particularly undeveloped and developing ones, affect the food system of our country in different ways. Therefore, one of the most important tasks of the current stage of economic and social development is to create conditions for ensuring food security for the population and saturating the market with high-quality, affordable food products. Besides, there is a thorny issue of saturating the market with domestic products that implies the volume growth of agricultural and food products and their competitive recovery.

Agriculture, which is the most important part of the agro-industrial complex, is exceptionally significant for the gradual development of the country's food market. The volume of domestic food-stuff production, its quality and cost effectiveness, not only of the living standards of the population but of the development of the economy as a whole. Agriculture is linked to almost all sectors of the economy, first of all, sectors like the food industry, bulk and retail trade. As a result, while making strategic plans for the development of the country's economy, the main focus is done on establishing competitive agriculture and food industry.

In 2012 the gross production of agriculture was KZT 1938847 million and if compared to 2004 it grew by 2,8 million tenge, including horticulture products by 2,3 million tenge and livestock products by 3,3 million tenge. However, such growth didn't lead to the establishment of a competitive agricultural sector which could compete with agricultural sectors of developed countries and partners of $\mathrm{CU}$. Throughout the years of the reforms, the proportion of agriculture in the country's GDP fell from 34\% in 1990 to 4,3\% in 2012 (Kamenova M.Zh., 2012).

Quality indicators of this sector such as cost-effectiveness, labour efficiency, yield capacity and productivity remain low. Large agricultural enterprises focused all their efforts on wheat production thus turning it into a "monoculture" which can easily be sold abroad. At the same time, the state of the farmland is getting worse as one and the same crops cannot be grown in one and the same field year by year. Yield capacity and the grain quality depend on the weather conditions, the amount of derelict farmland and the land which is no longer in agricultural use is increasing. For instance, a comparison between the yield capacity in Kazakhstan and similar figures in developed countries and countries of the Customs Union (CU) indicates a significant gap; even the yield capacity of irrigated land in Kazakhstan is (2-4times) lower than those in developed countries. For example, the yield of sugar beet in Kazakhstan is 200 quintal, in the USA $470 \mathrm{dt}$; the yield of cotton plant in Israel is 2.6 times higher than in Kazakhstan; the yield of vegetable crops is almost 4 times higher; and the yield of grain crops came up to 69,9 quintal in France, 58,4 quintal in the USA, 10,1 quintal in Kazakhstan, 35,2 in Belarus, 23,8 quintal in Russia.

It is fair to state that some of the reasons of such a significant gap are objective factors such as natural and climatic conditions, natural productivity of tilled fields and livestock yield which are considerably lower in Kazakhstan than in the USA or EU countries.

The most powerful AIC is formed in the USA. At the same time the proportion of the total workforce of the AIC comes up to only $12 \%$, whereas in agriculture it is $3 \%$. The highest degree of the American AIC development is defined not only by the level of economic development, but primarily by the level of agricultural development: 
- effective labour division among AIC sectors which enables high labour efficiency;

- industrial development of agriculture which, as a rule, leads to the reduction in the workforce (on account of high labour efficiency) and of non-marketed food products consumed by the rural population, as well as the increase of the urban non-rural population (Kotler Ph., 2005).

Kazakhstan AIC is characterized by an unbalanced sector structure, mainly the extensive development of agriculture. Also, one of the reasons for the low efficiency of the agricultural sector, in our opinion, is the small-scale nature of agricultural production. Analysis reveals that mainly private subsidiary farms (PSF) operate in the agricultural sector. Their share in the gross agricultural production has remained high $(52,7 \%$ in 2012) for a long time (Lamba J., 1996).

Structures such as that don't provide conditions for competition growth or the growth of labour efficiency.

\section{Results}

Governmental approaches to the agricultural sector have changed in the last decade, it was realized that small-scale enterprises cannot achieve the results that are expected from them. They are proposed to amalgamate and unite into cooperatives. However, it hasn't taken place and small-scale farms continue to predominate, and farmers refuse to unite into cooperatives. Highly publicized clusters which, as it is known from world practice, are one of the most effective integrated forms of the implementation of national competitive advantages, were not created (Drucker P., 1999).

There are a number of problems in the food industry, which is an important chain of the food market. The food industry can be characterized as a heterogeneous, multilevel, economic system, the activity of which is defined by a great variety of primary production, wide range of produced products, high diversification of forms, methods and means to organize the interaction between the different participants of production and commercial activities. This sector of the economy has great investment potential, it is characterized by a relatively low capital - output ratio and a high rate of turnover and return on investment. However, the status of the national food industry leaves much to be desired: the equipment is worn out, capacity is not used to its full extent and the labour efficiency is low. As a result, there is a steady fall of this sector's output in the industrial production

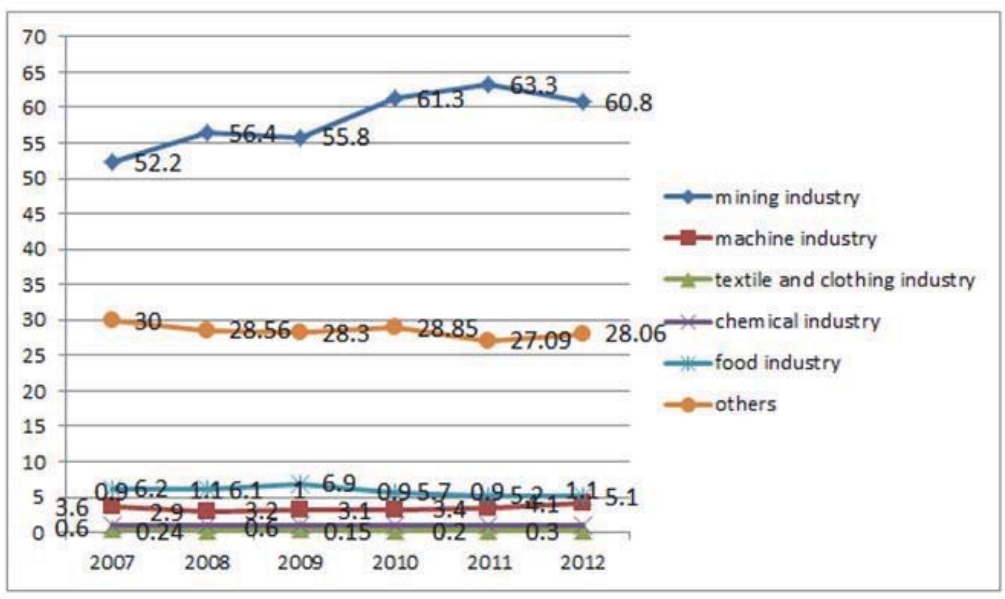

Figure 1. The structure of industrial production of Kazakhstan, 2007-2012, \%

Figure 1 depicts the current structure of our industry which reveals the negative tendencies existing in Kazakhstan's economy.

In particular, during the given period, the economy orientated to raw materials, which is proved by the growing proportion of the mining industry, whereas relative share of processing industries is decreasing. The scope of industrial production is comprised mainly by means of the mining industry $(60.8 \%)$, the share of food industry is $5.1 \%$, textile and clothing industry $-0.3 \%$, chemical industry $-1.1 \%$. Besides, a relatively steady development of these processes should be noted. For example, the proportion of the food industry decreased from $6.2 \%$ in 2007 to $5.1 \%$ in 2012. That is market transformations in the agricultural sector had not only positive results but a range of negative consequences for the development of industries that form the food market of Kazakhstan: 
- From our point of view, the main drawback of the market reforms at the initial stage was an attempt to achieve macroeconomic stability at any costs. The result of such an approach was the deterioration of the situation in the real sector of the economy, particularly, in agriculture and processing industries;

- Such processes as denationalization and privatization led to the reduction in the scope of government participation in the activities of AIC sectors, which had an adverse impact on their development. Consequently it led to negative structural changes, in particular, large-scale enterprises such as meat processing plants, poultry factories, agricultural enterprises lost their positions and were forced to leave the market because of the breakdown of the established supply system, the failure of materials and machinery supply, the increased competition, the lack of mobility and work experience in a new environment;

- The reforms significantly influenced the scope and structure of production, the price formation of the food products, led to the skewed ratio of the domestic products to imports while forming the goods supply, demand and supply and many others.

According to Kazakhstan's statistics agency, the production output of the food industry is implemented by 2219 enterprises. The substantial proportion in the structure of foodstuff production, including beverages, belongs to the grain processing industry $(30,0 \%)$, meat processing industry $(10,3 \%)$, dairy industry $(14,1 \%)$, fish processing industry $(0,9 \%)$, fruits and vegetables industry $(9,3 \%)$, oil and fat industry $(6,3 \%)$ and beverages production $(17,0 \%)$. In 2012 the enterprises of the food industry produced $5.1 \%$ of the national volume of industrial production and $22 \%$ of the volume of processing industry. According to the MA the work load capacity of processing enterprises is as follows:

- the production of flour - 37\%,

- pasta-51\%,

- vegetables $-28 \%$,

- $\quad$ sausage products $-28.4 \%$,

- processed milk - 47\%,

- $\quad$ butter -38\% (Kamenova M.Zh., 2012).

Figure 2 provides data with regards to the production volume of the basic types of foodstuff in Kazakhstan from 1990 to 2012. The given data enables us to conclude that in recent years there has been a growth in the production of the essential foodstuff. However, the comparison with 1990 reveals that we failed to achieve the pre-reform production level of a wide range of products. Thus, the production of meat in slaughter weight came up to 934.1 thousand tons in 2012 unlike 1524.4 thousand tons in 1990; the production of milk came up to 4851.6 versus 5642 thousand tons in 1990; egg production came up to 3673.4 million tons and 4185 million tons respectively.

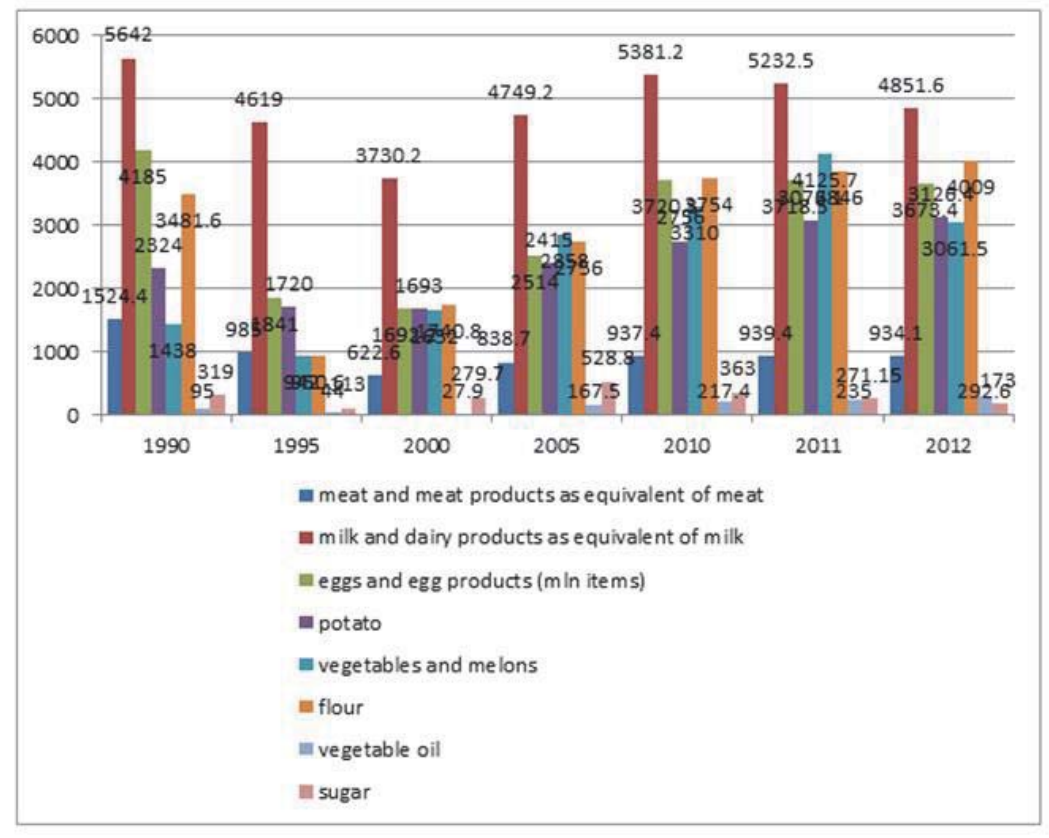

Figure 2. Production volume of the basic food stuff in 1990 - 2012, ths tons 
The current stage of Kazakhstan's development is characterized by the growth of standard and population's quality of living. The result of these processes is an increase in the population's foodstuff consumption. The volume of domestic production isn't enough anymore tomeettheincreaseddemand. The shortage of products is compensated by means of import. It should be noted that although the relative share of imported foodstuff is only $9.2 \%$ of total imports, there is a significant foodstuff dependence on import for many strategic food products.

For economic evaluation of the level of food market development, it is reasonable to consider the availability of foodstuff to people. The MA reports that the issue of national food security has been solved i.e. the country produces a sufficient number of foodstuff in compliance with consumption rates. According to our observations, scientifically based consumption rates for most foodstuff (meat, sugar, potatoes and etc) has not been reached. Between 1990 and 1995 the greatest problem was food shortage, whereas now the problem of food shortage has been solved by means of import. However, many products are no longer available to a significant part of the population which doesn't have enough money to buy them in sufficient quantities. Over the past few years the structure of the population's food consumption has changed considerably. The greatest proportion in this consumption structure belongs to cereals and came to $45,7 \%$ and $39,4 \%$ in 2005 and 2011 respectively i.e. the nutrient balance is mainly kept on account of starch-containing products which indicates the nutrition imbalance and the deficiency of vitamins and various microelements. The average per capita consumption of meat which is mainly an indicator of standard of living has been growing in recent years and is above the national consumption rates but below the health standards and below the level of the EU countries and the USA. In the structure of consumption, the proportion of meat came to $6.3 \%$ in 2005 and $8.4 \%$ in 2011. Besides, the proportion of import in the consumption of basic foodstuff is high and its volume is increasing at a rate much higher than the growth rate of agricultural products (Drucker P., 2007).

Table 1 presents data on production volumes, the ratio of export to import and the market capacity of agricultural products.

Table 1. Dynamics of market development of agricultural products of Kazakhstan in 2005-2012

\begin{tabular}{l|c|c|c|c|c|c|c|c}
\hline Criterion & 2005 & 2006 & 2007 & 2008 & 2009 & 2010 & 2011 & 2012 \\
\hline Production volume, billions of kzt & 674,16 & 853,2 & 1121,7 & 1384,1 & 1659,8 & 1442,6 & 2286 & 1938,8 \\
\hline Export, billions of kzt & 90,2 & 134,1 & 250.5 & 358,7 & 242,1 & 286,4 & 280,7 & 459,9 \\
\hline Import, billions of kzt & 169,3 & 209,5 & 278,8 & 359,9 & 363 & 340,1 & 608,3 & 647,5 \\
\hline Market capacity, billions of kzt & 753,26 & 928,6 & 1150 & 1385,3 & 1780,7 & 1496,3 & 2613,6 & 2126,4 \\
\hline The proportion of domestic products at the internal market, \% & 77,5 & 77,4 & 75,8 & 74,0 & 79,6 & 77,3 & 76,7 & 69,5 \\
\hline Footnote: data provided by Kazakhstan's Agency of Statistics & \multicolumn{7}{|l}{} \\
\hline
\end{tabular}

The table data analysis shows that the analyzed period is marked by the volume growth of agricultural products, their export and import whereas the import costs significantly exceed the export costs. Consequently, the proportion of domestic products at the internal market decreases. Situations like this have a negative impact on the country's food security.

Our observations do not confirm the official opinion, which states that the basic needs of the domestic market for foodstuffs are met by means of domestic production.

To analyze the current situation (Table 2) we studied the formation and the use of resources of essential food products.

Table 2. Resources and the use of certain types of raw materials and products in 2012 ths.tonnes

\begin{tabular}{|c|c|c|c|c|c|c|}
\hline Item & $\begin{array}{l}\text { Production, } \\
\text { ths. tonnes }\end{array}$ & $\begin{array}{l}\text { Import, } \\
\text { ths. tonnes }\end{array}$ & $\begin{array}{l}\text { Export, } \\
\text { ths. tonnes }\end{array}$ & $\begin{array}{l}\text { Market } \\
\text { capacity }\end{array}$ & $\begin{array}{c}\text { The proportion of consumed } \\
\text { domestic production, } \%\end{array}$ & $\begin{array}{c}\text { The proportion of } \\
\text { consumed import, } \%\end{array}$ \\
\hline 1 & 2 & 3 & 4 & 5 & 6 & 7 \\
\hline Flour & 3688,1 & 3,9 & 2219,1 & 1472,9 & 97,7 & 0,3 \\
\hline Pasta & 145,7 & 25,6 & 23,6 & 147,7 & 82,7 & 17,3 \\
\hline Meat and edible by-products & 934,1 & 314,5 & 3,2 & 1245,4 & 74,7 & 25,3 \\
\hline Domestic fowl and edible by-products & 123,1 & 203,7 & 1,4 & 325,4 & 37,4 & 62,4 \\
\hline Meat products: ready-made and tinned & 60,5 & 40,5 & 1,2 & 99,8 & 59,4 & 40,6 \\
\hline Sausage products & 39,6 & 34,8 & 14,7 & 59,7 & 41,7 & 47 \\
\hline Fish: ready-made and tinned & 32,5 & 57,1 & 20,1 & 69,5 & 17,8 & 82,2 \\
\hline Processed vegetables except potatoes & 17,8 & 75,1 & 2,1 & 90,8 & 17,3 & 82,7 \\
\hline Sugar & 146,9 & 267 & 2,2 & 411,7 & 35,1 & 64,9 \\
\hline Vegetable oil & 292,6 & 94,7 & 35,2 & 352,1 & 73,1 & 26,9 \\
\hline Butter & 12,2 & 8,1 & 0,02 & 20,3 & 60 & 40 \\
\hline Dairy products & 586,4 & 164,7 & 4,7 & 746,4 & 77,9 & 22,1 \\
\hline
\end{tabular}


The import proportion of consumption is huge in products like poultry meat where it is $62.4 \%$, fish: ready-made and tinned is $82.2 \%$, vegetables $-82.7 \%$, sugar $-64.9 \%$ as well as it is significant in products like meat products $-40.6 \%$, sausage products $-47 \%$, vegetable oil $-26.9 \%$, butter $-40 \%$, dairy products $-22.1 \%$

\section{Discussion}

First of all, the establishment of the private property altered the basic parameters of potential resources of the food sector, and caused the problems related to the structural deformations, the resources imbalance, in particular, the survival of domestic business which is forced to compete with foreign producers at international markets, as well as at the domestic food markets (Belov A.K., 2001).

The given data clearly shows that the formation process of the food market in Kazakhstan is not easy. To improve the situation, the government injects a lot of money into agricultural sector and has the right to expect good results. However, there is no mechanism which enables us to determine the effect of governmental support or to find out whether it was given to those who were supposed to get it. Numerous target programmes operating in AIC are not systematic, and at the present moment there is no integrated agro-food programme or a clear vision of where to move, or how to develop the AIC sectors (Sazonova R.S., 2006).

To establish a balanced food market it is important to have a strategy for the formation of a competitive, agrarian sector which is able to ensure food security; integration into the world food markets; to raise the level and standards of living; and sustainable development of rural territory. To do this it is important to create conditions for agriculture which are equal to those of other industries in the national economy by improving the mechanism of regulations and support. In particular, there are still complicated relationships between the agriculture industry and banks which unwillingly grant loans to the agricultural sector. The bankers' main argument is that there is high risk related to the dependence of agriculture production on weather conditions and thus credit default. The help of the government, from our point of view, should consist not only of the allocation of financial resources but the creation and development of structures of publicprivate partnership that would significantly reduce the risks (Mintzberg H., 2001).

It is necessary to stimulate the processes of amalgamation, establishment of cooperatives and other integrated entities which would enable to solve many agricultural problems. Particularly, the increase in product-quality, labourefficiency, the construction of infrastructure sites, and the possibility of getting loans.

The ways of solving the problems of industries which form the food market are reflected in the President's Address to the people of Kazakhstan. According to it, the problems of the AIC can be solved by the implementation of the following tasks:

- the innovation transition of AIC;

- establishment of an effective land market, letting land to be rented only if investments are attracted and new technology is applied in agriculture;

- elimination of barriers which prevent the development of the agriculture business, the corporation process, farming;

- boosting the implementation of the Concept of transition to a "green" economy, according to which $15 \%$ of cultivated land will have been transferred to water-efficient processes by 2030;

- network establishment of new processing enterprises in the agriculture sector, mainly, in forms of small and medium-sized businesses which should be supported by loans;

- implementation of technical re-equipment, reconstruction of existent enterprises in the shortest possible terms which would increase production volume, its quality and competitiveness;

- boosting the renewal of fixed assets of processing enterprises, a decrease in the period of mastering of a new, implemented production capacity;

- development of integrated processes enabling the possibility of expansion of the market outlet, effective implementation of the country's export potential;

- infrastructure development (wholesale markets, stock exchanges and etc.);

- development of a competitive environment, stimulation of the amalgamation processes, establishment of cooperatives and other integrated entities, increase in financial sustainability (G. Bekker, 2011). 


\section{References}

TasmambetovaA.Zh. Food market as a structural element of the market mechanism: economic nature, content and functions. Transit economy.- 2008.- № 5 / p.52-62

Bayadinova A. Major areas of functioning of subjects of the food market // Al-Pari. - 2006 № 3-4., p.197-198

Nazarbayev N.A. President of the Republic of Kazakhstan, January 17, 2014 Kazakhstan's way - 2050: The overarching goal, common interests, common future.

I. Pereverzev. Things are there. Expert Kazakhstan, № 1-4, January 2014.

Kamenova M.Zh. The competitiveness of the agricultural sector of the Republic of Kazakhstan: theory, practice and prospects in the post-crisis period Astana: 2012.- $247 \mathrm{p}$.

Philip Kotler. Principles of marketing. Prentice Hall/FinancialTimes, 2005. - 954 p.

Lamba Jean-Jacques. Strategic Marketing. European prospects $\neg$ va / Per. with fr.; - St. Science, 1996. - 589 p.

Drucker P. Management: Tasks, Responsibilities, Practices. HarperCollins Publishers, 1985, 839 p.

F Kotler. Marketing Management. Hardcover, Prentice Hall, 1999. - 784 p.

Milner BZ Management Science at the threshold of XXI century / / Problems of practice and theory of management. - 1998. - № 1. - P.913.

Drucker P. Management of the society of the future. - M. Williams, 2007. - 224.

Hayek F.A. Notes on the Evolution of Systems of Rules of Conduct. / / Hayek F.A. Studies on Philosophy and Economics. - London: Routledge and Kegan Paul, 1967. - P. 66-81.

Belov A.K. System forecasting for development of corporate structures. - M.: Publishing House "ALAIS", 2001, p.65-69.

Gordievsky F.D. Forecasting of socio-economic processes: principles and methods of long-term forecasting. - M.: ed. MEU, 2007. P.31-39.

Wilson A., Starbuck B. Forecasting and Strategic Planning. - Montreal: McGill University Press, 2006. R.72-73.Sazonova R.S., Mitin P.G. Forecasting and strategic planning of industrial activity: the principles and methods. - Novosibirsk: NITI, 2006. - P.122-124.

Mintzberg H. Guidelines for strategic positioning. - St. Petersburg: "Peter", 2001. - P.99-112.

G.Bekker Human Capital Online Resources/ /stepantsova.wordpress. com, 2011 